\title{
Diversity Assessment of Yield, Yield Contributing Traits, and Earliness of Advanced T-aman Rice (Oryza sativa L.) Lines
}

\author{
Md. Hasan Shahriar, Arif Hasan Khan Robin ${ }^{*}$ and Ahasanul Hoque \\ Department of Genetics and Plant Breeding, Bangladesh Agricultural University (BAU), \\ Mymensingh, Bangladesh \\ *Corresponding author: gpb21bau@gmail.com
}

\begin{abstract}
Thirty advanced T-aman rice (Oryza sativa L.) breeding lines along with four checks were studied at the experimental farm of the Department of Genetics and Plant Breeding, Bangladesh Agricultural University, Mymensingh. The experiment was conducted following Randomized Complete Block Design (RCBD) with three replications. The objective of the study was to know variability in yield, yield contributing characters and earliness of studied lines, and to identify short duration rice genotypes at $F_{9}$ generation. The genotypes differed significantly for plant height $(\mathrm{cm})$, length of panicle, total number of tiller per hill, effective tiller number per hill, filled grains per panicle, unfilled grains per panicle, days to 50\% flowering, days to maturity, 1000 grains weight and yield per plot $\left(K_{g}\right.$ plot $\left.^{-1}\right)$. Considering all the traits genotype $R 7$ was the earliest compared to all other genotypes which took 113 days for maturity. The genotype R16 recorded the highest yield, took 118 days for maturity, and that was significantly higher than check varieties. Phenotypic coefficient of variation (PCV) were higher than genotypic coefficient of variation $(G C V)$ for all the traits studied indicating that the measured traits interacted with the environment to some extent. All the studied traits expressed moderate to high heritability estimates. High heritability along with high genetic advance was noticed for the following traits: number of filled grain per panicle, number of unfilled grain per panicle and plant height. Data suggests a few promising breeding lines might be potential as short duration and high yielding $T$ aman variety.
\end{abstract}

Key words: Oryza sativa, variability, GCV, PCV, heritability, genetic advance, $F_{9}$ generation, advanced breeding lines

\section{Introduction}

Rice (Oryza sativa L.) is a crop belongs to Poaceae family, serve as a major carbohydrate sources for many nations all over the world. Bangladesh is mainly a rice growing country and majority of the arable lands are used only for rice cultivation. But nowadays, we are losing huge amount of cultivable land every year for infrastructure, garment industries and accommodation of ever-growing population (Mahmud, 2003). Basically, aman season provides lower yield potential than boro seasons but large amount of arable lands are utilized in aman rice cultivation in our country because of sufficient precipitation compared to boro season (Williams et al., 2006). Generally rice in boro season is late maturing compared to aman season. Early maturing crops are comparatively low yielding in any season but it may be balanced by less standing duration in the field. Moreover, short duration aman rice provides a window just enough for next short duration vegetable cultivation in the same piece of land. Thus, helps in increasing cropping intensity.

So, it is crucial to select short duration lines of aman without much sacrificing yield. In a successful rice improvement program, breeders provide efforts to accommodate the desirable characters to 
improve grain yield. Yield is a complex polygenic character where many of yield contributing characters form a complex chain of relationship with grain yield. Those yield contributing characters are highly influenced by environmental conditions (Doehlert et al., 2001). Magnitude and nature of variation as well as interrelationship of plant traits in a plant population lead to the progress of breeding.

A systematic and efficient breeding program involves the steps like creation of genetic variation, selection practices and utilization of selected genotypes to develop promising varieties and all of those steps involves biometrical and multivariate analyses (Ye et al., 2013; Peyman, 2012; Chakravorty et al., 2013). Estimation of heritability measures the information on flow of traits from parents to offspring. Estimation of heritability along with genetic advance is more helpful in selection than single heritability estimation. On the other hand, estimation of genotypic coefficient of variation (GCV) and phenotypic coefficient of variation (PCV) also play vital role in selection practice for an effective rice breeding program. The present study therefore was planned to estimate variability, heritability and genetic advance of selected advanced rice breeding lines at $\mathrm{F}_{9}$ generation with a vision to develop short duration and high yielding rice varieties in future.

\section{Materials and Method}

Thirty advanced breeding lines along with four check varieties viz. BINA dhan7, BRRI dhan 39, BRRI dhan 49, BRRI dhan 57 were used in the present study (Table 1). The advanced breeding lines were originated from the hybridazation programme carried out at International Rice Research Institute using different breeding lines under PETRA (Poverty Elimination through Rice Research Activities) project. A Randomized Complete Block Design with three replications was used to carry out the experiment. The individual plot size was $2.5 \mathrm{~m} \times 2 \mathrm{~m}(5$ square $\mathrm{m})$. Data were recorded to estimate the traits viz., plant height $(\mathrm{cm})$, length of panicle $(\mathrm{cm})$, total number of tiller per hill, effective tiller number per hill, filled grains per panicle, unfilled grains per panicle, days to 50\% flowering, days to maturity, 1000 grains weight $(\mathrm{g})$ and yield per plot $(\mathrm{kg})$.

Table 1. A list of the genotypes used in the experiment

\begin{tabular}{llll}
\hline S1. & Designation & Pedigree & Source \\
\hline 1 & R1 & Hy-23-29-32 & GPB, BAU \\
2 & R2 & Hy-3-281 & GPB, BAU \\
3 & R3 & Hy-5-407 & GPB, BAU \\
4 & R4 & Hy-7-435 & GPB, BAU \\
5 & R5 & Hy-10-584 & GPB, BAU \\
6 & R6 & Hy-10-648 & GPB, BAU \\
7 & R7 & Hy-11-818 & GPB, BAU \\
8 & R8 & Hy-15-926 & GPB, BAU \\
9 & R9 & Hy-15-927 & GPB, BAU \\
10 & R10 & Hy-17-1093 & GPB, BAU \\
11 & R11 & Hy-17-1059 & GPB, BAU \\
12 & R12 & Hy-17-1065 & GPB, BAU \\
13 & R13 & Hy-16-1192-7 & GPB, BAU \\
14 & R14 & IR 58082-126-1-2R & IRRI, Philippines \\
15 & R15 & BR 6017-3-1-1-3 & GPB, BAU \\
16 & R16 & BR 6017-3-3-4-1 & GPB, BAU \\
17 & R17 & IR 68926-61-2R & IRRI, Philippines \\
18 & R18 & IR 58082-126-1-2R & IRRI, Philippines \\
19 & R19 & BAU 94026-6-4-5-3-7-2-3-5 & GPB, BAU \\
20 & R20 & & \\
\hline
\end{tabular}




\begin{tabular}{llll}
\hline 21 & R21 & IR 68926-61-2R & IRRI, Philippines \\
22 & R22 & BR 4839-17-5-2-2HR5 & GPB, BAU \\
23 & R23 & Hy-8-554-54 & GPB, BAU \\
24 & R24 & BAU 94012-4-1-3-2-6-7-1-5 & GPB, BAU \\
25 & R25 & Hy-5-427-33 & GPB, BAU \\
26 & R26 & Hy-4-377-48 & GPB, BAU \\
27 & R27 & IR 72 & IRRI, Philippines \\
28 & R28 & BAU 92089-4-2-4-6-5-4-9-2 & GPB, BAU \\
29 & R29 & BR(BE) 6158-RWBC-7-11 & GPB, BAU \\
30 & R30 & Hy-9-765-10 & GPB, BAU \\
31 & R31 & BINA dhan7 & BINA, Mymensingh \\
32 & R32 & BRRI dhan39 & BRRI, Gazipur \\
33 & R33 & BRRI dhan49 & BRRI, Gazipur \\
34 & R34 & BRRI dhan57 & BRRI, Gazipur \\
\hline GPB= Department of Genetics and Plant Breeding, BAU= Bangladesh Agricultural University, \\
BRRI= Bangladesh Rice Research Institute, BINA= Bangladesh Institute of Nuclear Agriculture
\end{tabular}

\section{Estimation of genotypic and phenotypic variances}

Genotypic and phenotypic variances were estimated according to the formula given by Johnson et al. (1955).

Genotypic variance, $\sigma_{\mathrm{g}}^{2}=\frac{G M S-E M S}{r}$

Where,

GMS $=$ Genotypic mean square

EMS $=$ Error mean square

$\mathrm{r}=$ Number of replication

Phenotypic variance, $\sigma_{\mathrm{p}}^{2}=\sigma_{\mathrm{g}}^{2}+\sigma_{\mathrm{e}}^{2}$

Where, $\sigma_{\frac{g}{2}}^{2}=$ Genotypic variance

$\sigma_{\mathrm{e}}^{2}=$ Error mean square

Genotypic and phenotypic co-efficient of variations were estimated according to Burton (1952) and Singh and Chaudhary (1985).

Genotypic co-efficient of variations, GCV $=\frac{\sigma_{g}^{2}}{\bar{X}} \times 100$

Where, $\sigma_{g}^{2}=$ Genotypic variance; and

$$
\bar{X}=\text { Population mean }
$$

Phenotypic co-efficient of variations, $\mathrm{PCV}=\frac{\sigma^{2} p}{\bar{X}} \times 100$

Where, $\sigma^{2} p=$ Phenotypic variance; and

$$
\bar{X}=\text { Population mean }
$$

Heritability in broad sense $\left(\mathrm{h}^{2}{ }_{\mathrm{b}}\right)$ was estimated according to the formula suggested by Johnson et al. 
(1955) and Hanson et al. (1956).

Heritability, $\mathrm{h}_{\mathrm{b}}^{2}=\frac{\delta^{2}{ }_{g}}{\delta_{p}^{2}} \times 100$

Where,

$\delta_{\mathrm{g}}^{2}=$ Genotypic variance; and

$\delta_{\mathrm{p}}^{2}=$ Phenotypic variance.

Estimation of genetic advance was done following formula given by Allard (1960).

Genetic advance, $\mathrm{GA}=\mathrm{h}_{\mathrm{b}}^{2} \cdot \mathrm{K} \cdot \sigma_{\mathrm{p}}$

Where,

$\mathrm{h}_{\mathrm{b}}^{2}=$ Heritability

$\mathrm{K}=$ Selection differential, the value of which is 2.06 at $5 \%$ selection intensity

$\sigma_{\mathrm{p}}=$ Phenotypic standard deviation

\section{Statistical analysis}

Analyses of variances of the data were carried out using Minitab 17 statistical software package (Minitab Inc. State College, Pennsylvania).

\section{Results and Discussion}

\section{Analysis of variance}

Analysis of variance indicated that the difference among genotypes for all the traits under study viz., plant height $(\mathrm{cm})$, panicle length $(\mathrm{cm})$, tiller number per hill, effective tiller number per hill, filled grain per panicle, unfilled grain per panicle, days to $50 \%$ flowering, days to maturity and yield per plot $(\mathrm{kg})$ were highly significant (Table 2). Minimum days to maturity was approximately 113 days for genotype R7 (Table 2). These results suggested that these experimental materials might be used as precious germplasm to breed for earliness. Plant height, length of panicle, total tillers/hill, effective tillers/hill, filled grains/panicle, unfilled grains/panicle, days to $50 \%$ flowering, days to maturity, weight of 1000 grains (g) and yield/plot (kg) differed significantly across 34 rice genotypes (Table 3). Significant variation in yield contributing characters as observed, were also reported in some previous studies (e.g., Rahman et al. 2014; Seyoum et al. 2012; Bhadru et al. 2012; Courtois et al. 2012; Hossain et al. 2012; Peyman, 2012). 
Table 2. Mean sum of squares for different plant traits of 34 rice genotypes

\begin{tabular}{llll}
\hline \multirow{2}{*}{ Traits } & \multicolumn{3}{c}{ Source of variation } \\
\cline { 2 - 4 } & Replication (d.f.=2) & Genotype (d.f.=33) & Error (d.f.=66) \\
\hline PH & 3.59 & $164.5^{* *}$ & 6.95 \\
LP & 0.198 & $6.98^{* *}$ & 1.337 \\
TT & 1.032 & $3.6^{* *}$ & 1.017 \\
ET & 0.082 & $3.2^{* *}$ & 0.586 \\
FG & 24.55 & $674^{* *}$ & 25.18 \\
UFG & 9.199 & $192^{* *}$ & 10.02 \\
DF & -- & $45.5^{* *}$ & 5.735 \\
DM & -- & $9.18^{* *}$ & 5.980 \\
WT & -- & $38.2^{* *}$ & 0.627 \\
YD $(\mathrm{Kg})$ & -- & $0.401^{* *}$ & 0.035 \\
\hline
\end{tabular}

** indicates significant at 0.01 probability

$\mathrm{PH}=$ plant height $(\mathrm{cm}), \mathrm{LP}=$ length of panicle $(\mathrm{cm}), \mathrm{TT}=$ total tillers/hill, $\mathrm{ET}=$ effective tillers/hill, $\mathrm{FG}=$ filled grains/panicle, $\mathrm{UFG}=$ unfilled grains/panicle, $\mathrm{DF}=$ days to $50 \%$ flowering, $\mathrm{DM}=$ days to maturity, $\mathrm{WT}=$ weight 1000 grains $(\mathrm{g}), \mathrm{YD}=$ yield/plot $(\mathrm{Kg})$.

\section{Genotypic and phenotypic variability}

A wide range of variation was observed among 34 rice genotypes for nine yield contributing traits (Table 4). Data revealed that variance due to genotype was highly significant for all the traits (Table 4). The higher phenotypic variance values compared to genotypic variances indicated influences of environmental factor on these traits (Rahman et al., 2014). PCV were always higher than the corresponding GCV for all the traits indicating that they all have major environmental influences for regulating the traits (Table 4). Number unfilled grain per panicle had the highest estimates of GCV and PCV compared to any other traits (Table 4). Total tiller per panicle accounted for similar values of GCV and PCV with number effective tiller number per hill (Table 4). On the other hand, seed weight had very close GCV and PCV values with filled grain (Table 4). Plant height, length of panicle, days to flowering and days to maturity exhibited lower level of GCV and PCV (Table 4). The high values of GCV and PCV for these traits suggested the potential of yield improvement through selection of these traits. The estimates of PCV were always higher than GCV for all the traits (Table 4) which indicates all traits interacted with the environment to some extent (Bhadru et al., 2012). 
Table 3. Mean performances of 34 rice genotypes based on different morphological traits related to yield

\begin{tabular}{|c|c|c|c|c|c|c|c|c|c|c|c|}
\hline Genotypes & $\mathrm{PH}$ & LP & TT & ET & IT & $\mathrm{FG}$ & UFG & $\mathrm{DF}$ & DM & $\mathrm{WT}(\mathrm{gm})$ & $\mathrm{YD}(\mathrm{gm})$ \\
\hline R1 & 120 & 26.75 & 10.77 & 9.77 & 1.00 & 102 & 36.77 & 87.00 & 116.7 & 33.57 & 2040 \\
\hline $\mathrm{R} 2$ & 120 & 27.37 & 7.77 & 7.00 & 0.77 & 122 & 21.22 & 86.67 & 116.3 & 25.10 & 2093 \\
\hline R3 & 105 & 25.14 & 10.33 & 9.44 & 0.77 & 109 & 33.88 & 87.00 & 116.0 & 24.93 & 1740 \\
\hline $\mathrm{R} 4$ & 105 & 27.28 & 8.44 & 7.66 & 0.77 & 97 & 23.88 & 86.67 & 115.7 & 24.20 & 2657 \\
\hline R5 & 110 & 25.02 & 7.33 & 6.66 & 0.66 & 85 & 10.11 & 86.66 & 118.0 & 23.10 & 2333 \\
\hline R6 & 101 & 28.18 & 7.33 & 6.66 & 0.66 & 83 & 11.88 & 84.00 & 115.0 & 25.63 & 1613 \\
\hline R7 & 106 & 25.48 & 9.55 & 8.66 & 0.88 & 126 & 31.44 & 84.00 & 112.7 & 22.30 & 1570 \\
\hline $\mathrm{R} 8$ & 96 & 23.42 & 9.88 & 8.55 & 1.33 & 99 & 20.11 & 86.66 & 115.3 & 28.83 & 2257 \\
\hline R9 & 113 & 24.27 & 8.44 & 7.33 & 1.11 & 133 & 22.11 & 92.66 & 118.0 & 31.93 & 2270 \\
\hline $\mathrm{R} 10$ & 104 & 25.77 & 8.00 & 7.00 & 1.00 & 77 & 12.00 & 85.66 & 114.3 & 24.83 & 1967 \\
\hline R11 & 112 & 24.83 & 7.66 & 6.77 & 0.88 & 106 & 31.66 & 86.00 & 114.7 & 29.30 & 1970 \\
\hline $\mathrm{R} 12$ & 114 & 25.43 & 9.88 & 8.88 & 1.00 & 103 & 33.55 & 94.33 & 118.7 & 27.17 & 1973 \\
\hline R13 & 104 & 28.53 & 8.00 & 7.33 & 0.66 & 110 & 21.33 & 84.66 & 114.3 & 25.73 & 1813 \\
\hline R14 & 107 & 24.52 & 8.22 & 7.44 & 0.77 & 116 & 31.22 & 93.33 & 115.3 & 27.17 & 2003 \\
\hline R15 & 102 & 26.00 & 6.66 & 5.88 & 0.77 & 113 & 21.11 & 97.00 & 119.3 & 29.30 & 1810 \\
\hline R16 & 108 & 25.76 & 9.44 & 8.22 & 1.22 & 117 & 16.11 & 94.33 & 118.0 & 24.83 & 2757 \\
\hline R17 & 109 & 25.41 & 10.00 & 9.00 & 1.00 & 132 & 32.44 & 88.33 & 116.0 & 31.97 & 1897 \\
\hline R18 & 117 & 24.43 & 8.66 & 7.88 & 0.77 & 121 & 29.22 & 92.00 & 117.0 & 31.60 & 1613 \\
\hline R19 & 98 & 25.31 & 9.44 & 8.44 & 1.00 & 107 & 13.44 & 93.00 & 117.7 & 25.13 & 2727 \\
\hline R20 & 124 & 28.20 & 9.44 & 8.00 & 1.22 & 109 & 27.55 & 96.66 & 115.7 & 33.60 & 1977 \\
\hline R21 & 100 & 25.35 & 10.11 & 9.22 & 0.88 & 108 & 35.11 & 93.33 & 116 & 24.90 & 1103 \\
\hline $\mathrm{R} 22$ & 109 & 25.97 & 8.11 & 7.11 & 1.00 & 112 & 14.33 & 93.00 & 118 & 28.13 & 2230 \\
\hline $\mathrm{R} 23$ & 103 & 26.63 & 9.11 & 7.88 & 1.22 & 81 & 32.77 & 88.33 & 115 & 18.40 & 1563 \\
\hline R24 & 103 & 21.48 & 7.66 & 7.11 & 0.55 & 112 & 17.77 & 92.66 & 120.3 & 22.50 & 1920 \\
\hline $\mathrm{R} 25$ & 104 & 24.82 & 9.22 & 8.11 & 1.11 & 110 & 11.66 & 94.33 & 117.7 & 25.13 & 2117 \\
\hline R26 & 102 & 23.72 & 7.44 & 6.77 & 0.66 & 104 & 14.88 & 94.66 & 116.3 & 24.10 & 2097 \\
\hline R27 & 115 & 24.63 & 9.77 & 8.55 & 1.22 & 125 & 21.44 & 92.66 & 114.3 & 21.70 & 2703 \\
\hline R28 & 97 & 26.00 & 7.66 & 6.88 & 0.77 & 121 & 18.55 & 85.66 & 115.7 & 27.10 & 1733 \\
\hline R29 & 122 & 24.41 & 9.88 & 9.22 & 0.66 & 135 & 12.00 & 90.00 & 113.3 & 25.93 & 1903 \\
\hline
\end{tabular}


Published Online:23.09.2014, Vol.01(02): 102-112, 2014

\begin{tabular}{cccccccccccc} 
R30 & 111 & 22.67 & 9.88 & 8.88 & 1.00 & 111 & 26.11 & 88.33 & 115 & 26.73 & 2070 \\
R31 & 101 & 25.87 & 8.22 & 7.22 & 1.00 & 102 & 19.11 & 88.33 & 115 & 23.40 & 1967 \\
R32 & 112 & 24.63 & 9.88 & 9.22 & 0.66 & 130 & 29.55 & 87.00 & 114.7 & 20.00 & 2153 \\
R33 & 100 & 26.10 & 9.55 & 8.55 & 1.00 & 123 & 26.55 & 85.00 & 113.7 & 26.50 & 1853 \\
R34 & 102 & 23.64 & 10.44 & 9.88 & 0.55 & 88 & 20.66 & 92.00 & 115.7 & 26.63 & 2563 \\
\hline Minimum & 96 & 21.48 & 6.66 & 5.88 & 0.55 & 77 & 10.11 & 84.00 & 112.7 & 18.40 & 1103 \\
Maximum & 124 & 28.53 & 10.77 & 9.88 & 1.33 & 135 & 36.77 & 97.00 & 120.3 & 33.60 & 2757 \\
Mean & 108 & 25.38 & 8.88 & 7.98 & 0.90 & 110 & 22.99 & 89.76 & 116.0 & 26.21 & 2031 \\
SEM & 1.52 & 0.66 & 0.58 & 0.44 & 0.29 & 2.89 & 1.82 & 1.38 & 1.41 & 0.42 & 107.9 \\
P value & $<0.01$ & $<0.01$ & $<0.01$ & $<0.01$ & $<0.01$ & $<0.01$ & $<0.01$ & $<0.01$ & $<0.01$ & $<0.01$ & $<0.01$ \\
\hline
\end{tabular}

$\mathrm{PH}=$ plant height $(\mathrm{cm}), \mathrm{LP}=$ length of panicle $(\mathrm{cm}), \mathrm{TT}=$ total tillers/hill, $\mathrm{ET}=$ effective tillers/hill, $\mathrm{FG}=$ filled grains/panicle, $\mathrm{UFG}=$ unfilled grains/panicle, $\mathrm{DF}=$ days to $50 \%$ flowering, $\mathrm{DM}=$ days to maturity, $\mathrm{WT}=$ weight of 1000 grains $(\mathrm{g}), \mathrm{YD}=$ yield/plot $(\mathrm{Kg})$.

$\mathrm{SEM}=$ Standard error of mean, $\mathrm{P}=$ probability of statistical significance in generalized linear model 
Table 4. Genetic parameters of 34 rice genotypes based on different yield related morphological traits

\begin{tabular}{lllllllll}
\hline Traits & $\begin{array}{l}\text { Genotypic } \\
\text { variance } \\
\left(\sigma_{\mathrm{g}}^{2}\right)\end{array}$ & $\begin{array}{l}\text { Phenotypic } \\
\text { variance } \\
\left(\sigma_{\mathrm{ph}}^{2}\right)\end{array}$ & $\begin{array}{l}\text { Grand } \\
\text { mean }\end{array}$ & $\begin{array}{l}\text { Heritability, } \\
\mathrm{h}_{\mathrm{b}}^{2}(\%)\end{array}$ & GCV $(\%)$ & PCV $(\%)$ & $\mathrm{GA}$ & $\mathrm{GA}(\%)$ \\
\hline PH & 52.5 & 59.5 & 108 & 88.3 & 6.74 & 7.17 & 14.0 & 13.1 \\
LP & 1.88 & 3.22 & 25.4 & 58.4 & 5.40 & 7.07 & 2.16 & 8.50 \\
TT & 0.86 & 1.88 & 8.89 & 45.8 & 10.5 & 15.4 & 1.30 & 14.6 \\
ET & 0.87 & 1.46 & 7.98 & 59.6 & 11.7 & 15.1 & 1.48 & 18.6 \\
FG & 216 & 241 & 110 & 89.6 & 13.4 & 14.2 & 28.7 & 26.2 \\
UFG & 60.8 & 70.9 & 22.9 & 85.9 & 33.9 & 36.6 & 14.9 & 64.8 \\
DF & 13.3 & 18.9 & 89.8 & 69.8 & 4.06 & 4.86 & 6.27 & 6.98 \\
DM & 1.07 & 7.05 & 116 & 15.2 & 0.89 & 2.29 & 0.83 & 0.72 \\
WT & 12.6 & 13.2 & 26.2 & 95.9 & 13.6 & 13.8 & 7.17 & 27.4 \\
\hline
\end{tabular}

$\mathrm{PH}=$ plant height $(\mathrm{cm}), \mathrm{LP}=$ length of panicle $(\mathrm{cm}), \mathrm{TT}=$ total tillers/hill, $\mathrm{ET}=$ effective tillers/hill, $\mathrm{FG}=$ filled grains/panicle, $\mathrm{UFG}=$ unfilled grains/panicle, $\mathrm{DF}=$ days to $50 \%$ flowering, $\mathrm{DM}=$ days to maturity, WT= weight of 1000 grains (g), PCV= Phenotypic coefficient of variation, GCV= Genotypic coefficient of variation, GA= Genetic advance, GA $(\%)=$ Genetic advance as percent of mean

\section{Heritability}

The estimates of heritability act as predictive instrument in expressing the reliability of phenotypic value. Therefore, high heritability helps in effective selection for a particular trait. The traits studied in the present investigation expressed low to high heritability estimates ranging from 15 to 96 percent (Table 4). The highest heritability was recorded for weight of 1000 seeds $(95.9 \%)$ followed by number of filled grain per panicle, plant height, unfilled grain per panicle, days to 50\% flowering, effective tiller per hill, length of panicle, total number of tiller. The lowest heritability value was recorded for days to maturity (Table 4). High heritability values indicate that the traits under study are less influenced by environment in their expression (Akinwale et al., 2011). It also indicates the scope of genetic improvement of these traits through selection. Thus, a breeder may make his selection securely on the basis of phenotypic expression of these traits on the individual plant.

\section{Genetic advance}

The genetic advance is a useful indicator of the progress that can be expected as result of exercising selection on the pertinent population. Heritability in conjunction with genetic advance would give a more reliable index of better selection value (Akinwale et al. 2011). In the present study genetic advance was the highest for number of filled grains per panicle (28.7) followed by unfilled grain per panicle and the lowest for days to maturity (0.83) among yield contributing traits (Table 4). The genetic advance as percent of mean was the highest in case of unfilled grain per panicle while it was the lowest for days to maturity (Table 4). If selection is made for improving the particular trait under study; one should focus on heritability and genetic advance. The information on genetic variation, heritability and genetic advance help to predict the genetic gain that could be obtained in later generations. High heritability with high genetic advance exhibited by the traits, controlled by additive gene action (Panse, 1957; Hasan et al. 2013; Prasad et al. 2001; Singh et al. 2013) and can be improved through simple or progeny selection methods. Selection for the traits having high heritability associated with high genetic advance leads to 
accumulate more additive genes. It can enhance the opportunities for further improvements of their performance. In the present study, high heritability along with high genetic advance was noticed for the traits: number of filled grain per panicle, unfilled grain per panicle and plant height. Other traits showed high heritability along with moderate or low genetic advance which can be improved by intermating superior genotypes of segregating population (Prajapati et al., 2011).

\section{Conclusions}

The phenotypic coefficients of variation of all studied traits were higher than genotypic coefficient of variation which indicating that they all interacted with the environment to some extent. The traits studied in the present investigation exhibited low, moderate and high PCV and GCV values. Among all of the traits, unfilled grain per panicle exhibited the highest estimates of GCV and PCV followed by seed weight and number of filled grain per panicle. The lowest PCV and GCV values were recorded for days to maturity.

The studied traits expressed low to high heritability estimates ranging from 15 to 96 percent. Among the traits, the highest heritability was recorded for 1000 seed weight followed by number of filled grain per panicle, plant height, unfilled grain per panicle, days to 50\% flowering, effective tiller per plant, length of panicle, total tiller per hilland days to maturity. The lowest heritability value was recorded for days to maturity. High heritability values indicated that the traits under study were less influenced by environment in their expression.

Genetic advance was the highest for number of filled grains per panicle followed by unfilled grain per panicle and plant height. The lowest genetic advance was obtained in days to maturity. In this study, high heritability along with high genetic advance was noticed for filled grain per panicle, unfilled grain per panicle and plant height. These traits can be improved through simple or progeny selection methods. Other traits showed high heritability along with moderate or low genetic advance. These traits can be improved by inter-mating superior genotypes of segregating population developed from combination breeding.

In this study 30 advanced rice breeding lines at $\mathrm{F}_{9}$ exhibited high variability. The results therefore suggested that selecting a line for shorter growth duration of 113 days with comparatively higher yield would be possible from those genotypes.

\section{Acknowledgements}

The authors gratefully acknowledge valued comments and suggestions of Professor Md. Wazuddin and Associate Professor Sharif Ar-Raffi, Department of Genetics and Plant Breeding, Bangladesh Agricultural University, Mymensingh, Bangladesh during the study period. 


\section{References}

Akinwale, M., Gregorio, G., Nwilene, F., Akinyele, B., Ogunbayo, S. \& Odiyi, A. (2011). Heritabilityand correlation coefficient analysis for yield and its components in rice (Oryza sativa L.). African Journal of Plant Science 5(3): 207-212.

Allard, R.W. (1960). Principles of plant breeding. John Wiley and Sons. Inc., New York.

Bhadru, D., Rao, V. T., Mohan, Y. C. \& Bharathi, D. (2012). Genetic variability and diversity studies inyield and its component traits in rice (Oryza sativa L.). SABRAO Journal of Breeding and Genetics 44(1): 129-137.

Burton, G. W. (1952). Quantitative inheritance in Grasses. Proc. 6th International Grassland Congress 1: 277-283.

Chakravorty, A., Ghosh, P. \& Sahu, P. (2013). Multivariate analysis of phenotypic diversity of landraces of rice of West Bengal. American Journal of Experimental Agriculture 3(1): 110-123.

Courtois, B., Sinha, P., Prasad, K. \& Carandang, S. (2012). Genetic diversity among upland rice varieties from India and Bangladesh. International Rice Research Notes 22(3): 8-9.

Doehlert, D. C., McMullen, M. S. \& Hammond, J. J. (2001). Genotypic and environmental effects on grain yield and quality of oat grown in North Dakota. Crop Science 41(4): 1066-1072.

Hanson, C., Robinson, H. \& Comstock, R. (1956). Biometrical studies of yield in segregating populations of Korean Lespedeza. Agronomy Journal 48(6): 268-272.

Hasan, M., Kulsum, M., Akter, A., Masuduzzaman, A. \& Ramesha, M. (2013). Genetic variability and character association for agronomic traits in hybrid rice (Oryza Sativa L.). Bangladesh Journal of Plant Breeding and Genetics 24(1): 45-51.

Hossain, M., Islam, M., Hossain, H., Ali, M., Teixeira da Silva, J., Komamine, A. \& Prodhan, S. H. (2012). Genetic diversity analysis of aromatic landraces of rice (Oryza sativa L.) by microsatellite markers. Genes, Genomes and Genomics 6: 42-47.

Johnson, H. W., Robinson, H. \& Comstock, R. (1955). Estimates of genetic and environmental variability in soybeans. Agronomy Journal 47(7): 314-318.

Mahmud, W. (2003). Bangladesh: development outcomes and challenges in the context of globalization. Paper presented at the conference on The Future of Globalization: Explorations in Light of Recent Turbulence co-sponsored by the Yale Center for the Study of Globalization and the World Bank, October 10-11, 2003, Yale University.

Panse, V. (1957). Genetics of quantitative characters in relation to plant breeding. Indian Journal of Genetics 17(2): 318-328.

Peyman, S. (2012). Diallel analysis to study genetic parameters of rice salinity tolerance traits at germination stage. SABRAO Journal of Breeding and Genetics 44(1):42-57.

Prajapati, M. K., Singh, C. M., Babu, G. S., Lavanya, G. R. \& Jadhav, P. (2011). Research Note Geneticparameters for grain yield and its component characters in rice. Electronic Journal of Plant Breeding 2(2): 235-238.

Prasad, B., Patwary, A. \& Biswas, P. (2001). Genetic variability and selection criteria in fine rice (Oryza sativa L.). Pakistan Journal of Biologial Science 4(10): 1188-1190.

Rahman, M. M., Syed, M., Akter, A., Alam, M. M. \& Ahsan, M. M. (2014). Genetic Variability, Correlation and Path Coefficient Analysis of Morphological Traits in Transplanted Aman Rice (Oryza sativa L.).American-Eurasian Journal of Agricultural \& Environmental Science 14 (5): 387 391.

Seyoum, M., Alamerew, S. \& Bantte, K. (2012). Genetic variability, heritability, correlation coefficient and path analysis for yield and yield related traits in upland rice (Oryza sativa L.). Journal of Plant Sciences 7(1): 13-22.

Singh, R. K. \& Choudhury, B. D. (1985). Biometrical method in quantitative genetic analysis. Kalyani Publishers, Ludhiana, New Delhi. 
Singh, A., Sharma, P. \& Singh, P. (2013). Studies on Genetic Characteristic of Upland Rice (Oryza sativa L.). International Journal of Agriculture, Environment and Biotechnology 6(4): 515-520.

Williams, P., Islam, M., Adomako, E., Raab, A., Hossain, S., Zhu, Y., Feldmann, J. \& Meharg, A. (2006). Increase in rice grain arsenic for regions of Bangladesh irrigating paddies with elevated arsenic in groundwaters. Environmental Science \& Technology 40(16): 4903-4908.

Ye, G., Collard, B., Zhao, X. \& Nissila, E. (2013). Enhancing rice breeding efficiency: the role of breeding informatics. SABRAO Journal of Breeding and Genetics 45(1): 143-158.

\section{Citation for this article (APA Style)}

Shahriar, M. H., Robin, A. H. K., \& Hoque, A. (2014). Diversity assessment of yield, yield contributing traits, and earliness of advanced T-aman rice (Oryza sativa L.) lines. Journal of Bioscience and Agriculture Research, 01(02), 102-112. Retrieved September 23, 2014, from http://www.journalbinet.com/current-issue.html. 